to those assembled at New Iberia and Alexandria, the number of new members elected being 12 at New Yberia, 16 at Alexandria, and 16 at Monroe; total new members added to the Louisiana State Medical Society in I 886 , I 887 and I 888,44 . The total number of permanent members to the meeting at New Iberia was I5O; thus we have during the past three years an increment of nearly 30 per cent., or, more accurately, 29.3 per cent. When we reflect that the Louisiana State Medical Society had practically no existence until i 878 , we must regard the steady increase in its members as proof that the medical profession in Louisiana regard its membership as an honor.

In medical attainments, earnestness, courteous and manly bearing, the medical gentlemen who assembled at Monroe, were the peers of the members of any similar gathering in Louisiana or any other State in this Republic.

The daily sessions were distinguished by careful and continuous scientific and executive labors, by harmony, and by courteous regard to parliamentary rules. The entire time of the sessions was devoted to the reading and discussion of papers, and the transaction of important business. The relative amount of scientific work accomplished may be seen from the following record of the past three meetings of the State Medical Society: Number of papers read at the New Iberia meeting, in I886, I I number of papers read at Alexandria, I887, I6; number of papers read at Monroe, I 888, I4. Total, 4I.

The character of the labors of the State Medical Society at Monroe will be shown to the medical profession in due time in the printed Transactions of I 888 , which will vindicate the high attainments of the representatives of the regular medical profession.

The results of the meeting at Monroe are especially worthy of note when it is considered that the State of Louisiana had just passed through a heated political campaign, which had engaged the close attention and monopolized the energies of the citizens for several months; and when it is also remembered that Monroe is the most distant town from the large centres of population at which a meeting has been held, and is also comparatively inaccessible.

Louisiana suffered severely during the Civil War of I86I-I865, which overthrew her system of labor and destroyed the lives of many of her citizens. It was not until 1877 that there was any proper recognition by the Federal Government of the political and civil rights of a citizen of Louisiana.

With this change came the revival of the State Medical Society, and the little band of medical men, devoted to the advancement of the interests of the citizens and to the profession of their beloved State, has been steadily marching onwards, with the hope that they will, in time, enroll within their ranks every honorable member of the regular medical profession, and gradually perfect and establish all measures relating to the elevation and protection of the medical profession of Louisiana. It is not truc, therefore, that " the Tenth Annual Meeting of the State Medical Society, at Monroe, Louisiana, was characterized by indifference, idleness and slip-shod irresponsibility."

It is not true, therefore that "the meetings of the Louisiana Medical Society are the straggling together of a dozen or so, of languid, inconsequent, unprepared medical men, bent for the most part upon a few days of rest, cigar-smoking and storytelling." Respectfully submitted, JOSEPH JONES, M.D.,

Late President of Louisiana State Medical Society, Presiding Officer, Monroe, La., April 25 and 26, I 888 , New Orleans, La.

J. J. Newton, Jr., M.D., President Louisiana State Medical Society, Bastrop, La.

Richard H. Day, M.D., Ex-President Louisiana State Medical Society, Baton Rouge, La.

T. O. Brewer, M.D., Chairman of the Committee of Arrangements for the Tenth Annual Meeting of the Louisiana Medical Society ; and VicePresident for the Fifth Congressional District, Monroe, I,a.

J. D. Dupreé, M.D., Ex-President Louisana State Medical Society, Baton Rouge, La.

G. G. Belford, M.D., Bastrop, La.

Thomas Buffington, M.D., Baton Rouge, La.

T. G. Bridges, M.D., Bastrop, La.

W. R. McCreight, M.D., Bastrop, La.

T. M. Thornhill, M.D., Ex-Vice-President for the Fourth Congressional District, Arcadia, La.

J. M. Patterson, M.D.,Arcadia, La.

W. O. White, M.D., Vice-President Third Congressional District, Abbeville, La.

J. C. Brown, M.D., Arcadia, La.

W. R. Aishman, M.D., President Vermillion Parish Medical Society, and other members of the Louisiana State Medical Society.

\section{Transactions Ninth International Medical Congress Corrections.}

Dear Sir: As The Journal seems the medium through which information will most promptly reach the largest number of readers of the Transactions of the Ninth International Medical Congress, I ask you to publish the following corrections :

Vol. II, page 34 , line 9 , for "equations ( $\frac{150+60}{20}$ ) $\times 2640=42240$," read, "equation $\left(\frac{150+60}{20}\right) \times$ $2640=27.720 . "$

Page 39, line 20, for "great ration," read given ration."

Page 40, third line from bottom, for " 0.576 ," read, 0.0576 . 
Page 4o, tenth line from bottom, for (V1de. p. 8 ) read, (Vide. p. 36 ).

Page 44 , line $I_{3}$, for figures on page 40 , read "figures on page 41 , wiz. N $17 .-C 562$ grs."

Page 47, Total Ration B., for "30. oz." read 30. 4 oz.

Your obedient servant, Jos. R. SMITH,

Licut-Col. and Surgeon, U.S. Army. St. Yaul, Minn., June 27, 1888 .

\section{NECROLOGY.}

\section{A. Y. P. GARNETT, M.D.}

GARNeTT (AleXANDER Yelderton PAy'TON), M.D., of Washington City, was born in Essex County, Va., Sept. I9, I820, and died suddenly of heart failure, at the "Bright House," Rehoboth Beach, Delaware, on the evening of July i I, I888. He was the son of Muscoe and Maria Wills Battle Garnett, who resided on a productive plantation near the Rappohanock River. One brother, an eminent lawyer, resides in Richmond, Va. As was the custom with well-to-do Virginians, when the doctor was a youth he was taught by private instructors, in his father's house. There he acquired a substantial education, including a knowledge of the classics and of French. Having selected medicine as a profession, and having read over the text-books, he attended the usual course of Lectures at the University of Pennsylvania, and received therefrom the degree of M.D. in I84I. His thesis submitted to the faculty on the occasion was on "Extra-uterine Gestation."

Shortly after obtaining his degree he presented himself before a Board of Naval Surgeons, and having passed a satisfactory examination, was commissioned an Assistant Surgeon in the U. S. Navy. In a few years he was promoted to PostAssistant Surgeon. After serving for five years at sea in different parts of the world, he was stationed at the Navy Yard in Washington. Having married and desiring to be with his family, in I 848, he resigned from the service, and began practice in Washington. In $185 \mathrm{I}$ he was enrolled as a member of the Medical Society, of the District of Columbia, and also a member of the Medical Association of the D. C. the same year. He joined the Pathological Society about the same time, and in $185^{2}$ he was elected its secretary. In these he held in succession the various offices, including that of the presidency. In $185^{2}$ he became a member of the American Medical Association, an or-; stant and careful reader of the latest and best ganization to which he was much attached, and works available.

attended its meetings in $1853,56,68,70,76,8 \mathrm{r}$, Dr. Garnett's practice in Washington, as it had $83,84,85,86,87$ and 1888 . The last year he been in Richmond, was largely among the élite, was the president-elect and presiding officer, and delivered on the occasion of his taking the chair, a most able address.

Dr. Garnett was one of the original members of the American Climatological Society, and presented to it some able papers, and had one in course of preparation to be read at its next meeting. About I 858 he was appointed physician to the United States Penitentary, which then and until after the war, stood at the foot of $4 \frac{1}{2}$ Street. The remaining parts of the old prison are now enclosed within the Arsenal or U. S. Artillery parade grounds. In 1858 he was elected Professor of Clinical Medicine in the National Medical College. Dr. Garnett "went south," as it is generally phrased, at the beginning of the war between the States, and, of course, vacated his chair in the medical faculty. During the Civil War he served as surgeon in the Confederate States Army, and was placed on duty in Richmond and had charge of two hospitals, and was at the same time a member of the Board of Medical Examiners for the Confederate Army. His professional ability, his character as a man, and his elegant address made him a favorite so that he was much employed as a family physician as well as sought after by the heads of the Confederate Government and officers on duty at Richmond. He was not only the physician and a valued trusted friend of Jefferson Davis, President of the Southern Confederacy, but of Gen. Lee and his family, and of most, if not all the families of the Cabinet officers of the Confederacy. He remained at the post assigned him until the surrender at Appomatox, and a new order of things assumed control. The cause for which he started life and fortune was lost. But the Union was saved. With health shattered, but with a brave heart, he returned to Washington a poor man, to begin life, as it were, again. Dr. Garnett had, before the war, by his energy and devotion to his profession, acquired considerable property in Washington. His life estate on this was, as a matter of course, confiscated by the Government of the United States. He was, however, enabled after a time to repurchase a portion of his property, and in this way saved something from the wreck.

Some time after resuming his practice, he was elected to the Chair of Practice in the National Medical College which he filled with ability until he resigned in 1870 , because of the increasing demand upon his time by professional engagements when he was elected Emeritus Professor, which position he held at the time of his death. He was always a well prepared, fluent, graceful and entertaining lecturer, because he was a con- 